\title{
Promoting Education for Sustainable Development: Challenges and Issues for Higher Education Institutions in Pakistan
}

\author{
Shahid Hussain Mughal \\ (Corresponding Author) \\ Assistant Professor, Sukkur Institute of Business Administration (IBA), Faculty of Education, \\ Sukkur, Sindh, Pakistan \\ Email: smughal38@yahoo.com \\ Dr.Nasim Qaisrani \\ Professor, Iqra University, Gulshan Campus, Karachi, Pakistan
}

Ghulam Mohuyuddin Solangi

Ph.D Scholar, Iqra University, Karachi, Pakistan

Email: ghulammuhiyuddin@yahoo.com

Sumaira Faiz

Ph.D Scholar, Iqra University, Karachi, Pakistan

Email: faiz_sumaira@yahoo.com

Accepted: November 10, 2011 Published: December 04, 2011

Doi:10.5296/ijld.v1i1.1131ＵRL: http://dx.doi.org/10.5296/ijld.v1i1.1131

\begin{abstract}
Education is critical agent of transformation in terms of changing life styles, attitude and behavior. The role of education in pursuit of Sustainable Development is indispensable. The United Nations Conference on Environment and Development (1987) used the term Sustainable Development. According to UN Commission (known as Brundtland Commission) Sustainable Development is "development that meets the needs of the present generation without compromising the needs of future generation." Sustainable Development talks about
\end{abstract}


environmental problems and its solution in a broader perspective. It takes into account social, political, cultural and economic aspects. The United Nations has declared 2005-2014 as the decade for Education for Sustainable Development. Since the 1993 Kyoto Declaration on Sustainable Development, the role of higher education has become vital.

The recent trend in the depletion of natural resources, energy, water and food crises, has increased and challenged the role of higher education institutions in Pakistan. The question arises "To what extent our higher education \& research institutions are playing their role in order to ameliorate the situation? The other questions that come to mind are "how higher education institutions can respond to prevailing intricate situation? And what role can these institutions play for promoting education for sustainability?

This research study intends to critically examine the role of higher education institutions for the promotion of education for sustainability and to explore the opportunities for the integration of education for sustainability considerations in the existing courses being offered in the universities of Pakistan. This study intends to analyze the National Conservation strategy (NCS) of Pakistan with reference to the promotion of education for sustainability.

Key Words: Education for sustainability, Higher Education, National Conservation Strategy, Integration

\section{Introduction}

There is growing concern about the state of the environment all around the world. Environmental issues, such as rapidly increasing global warming, ozone depletion, dwindling resources, famine, disease, loss of the world's forests, pollution, have captured the attention of the world. The recent depletion in natural resources has put the survival of humanity at risk. If we use up all the resources, what will the future generations do? The World Commission on Environmental Development (WCED) introduced the idea of sustainable development. According to WCED "sustainable development seeks to meet the needs and aspirations of the present generations, without compromising the ability to meet those of ... future generations." (WCED, 1987, cited in Alvi \& Aziz, p.5). The UN Conference on Environment and Development, which was held in 1992 in Rio de Janeiro, has recognized the importance of training on environment and sustainable development. The World Summit on Sustainable Development 2002, which was held in Johannesburg, South Africa, also confirms this in Agenda 21. The agenda 21 states, "education is critical for promoting sustainable development and improving the capacity of the people to address sustainable issues."(UNESCO-UNEP, 1994). Education is critical agent of transformation in terms of changing life styles, attitude and behavior. The role of education in pursuit of Sustainable Development is indispensable. Sustainable Development talks about environmental problems and its solution in a broader perspective. It takes into account social, political, cultural and economic aspects. In December 2002, the United Nations General Assembly declared the period from 2005 to 2014 the Decade of Education for Sustainable Development (DESD). DESD dreams and envisions a world where everyone has the opportunity to benefit from education, and learn the values, behavior and lifestyles essential for a sustainable future and for positive societal transformation. Hence, if different communities and nations hope to achieve sustainability 
goals, basic education must be reoriented to integrate ESD at all the stages of education - pre-primary, primary, secondary, higher secondary and advanced - and within all forms of the existing educational set-up, i.e. formal and otherwise. (Gupta, 2007).

Since the 1993 Kyoto Declaration on Sustainable Development, the role of higher education has become vital. The question arises "To what extent our higher education \& research institutions have played their role in order to ameliorate the situation? The other questions that come to mind are "how higher education institutions have responded to prevailing intricate situation? And what role these institutions have played for promoting education for sustainability? In order to respond these questions a detailed analysis has been done.

\subsection{Purpose of the Study}

The purpose of this study was:

1. To examine the role of Higher education Institutions for the integration of sustainable development considerations and practices into their curricula,

2. To review National Conservation Strategy with reference to the role of Higher education Institutions and

3. To suggest strategies "How ESD themes in existing programs (offered at higher education institutions of Pakistan) can be incorporated?

\subsection{Methodology}

The following documents/ Policies have been reviewed to address the raised issues:

- The National Education Policy of Pakistan 1998-2010

- $\quad$ National Conservation Strategy( NCS)

- $\quad$ Final Report of International Commission on Education for Sustainable Development Practice(2008)

- $\quad$ Other related literature/ Discussions with IUCN/ WWF representatives in Pakistan has also been critically analyzed and incorporated in the paper.

\section{The Current Scenario regarding ESD in Pakistan: A Critical Review}

Appreciating the importance of environmental education in promotion of sustainable development, conservation strategies are undertaken by nations as a step toward sustainable development. These strategies help assess availability of vital resources, their most appropriate use, means and methods of their conservation for optimum use in the present, while maintaining a balance for potential use in the future for the growth and development of the society. Development then involves a progressive transformation of economy and society for the satisfaction of human needs and aspirations. However, development brings in its wake degradation not only of the resources, but also the environment from which these resources are made available. The scenario calls for sustainability of the resources as well as the supporting environment (Arif, 1997). Sustainable Development therefore encompasses meeting the basic needs of all and extending to all, the opportunity to satisfy their aspirations for a better life. (Arif, 1997).Pakistan is blessed with a lot of natural resources, from mountains, forests, wild 
life, rivers, and oceans to a variety of weathers. Pakistan is a signatory of several international conventions and protocols, such as the framework on climate change, Rio de Janeiro, 1992. The most significant event in the conservation movement in Pakistan was the adoption of the National Conservation strategy (NCS) in 1992. It was a policy document, which called for environmental improvement and sustainable development in all aspects of life (IUCN, 1999).

Arif (1997) reports that the need for environmental education was also emphasized by the NCS. In 1996, the NCS Unit developed the strategy for Mass Environmental Awareness and Education. The Pakistan National Education Policy 1998-2010 reflects the growing concern for the country's environment. The main objective of the policy was to overhaul the education system in the light of modern trends in education, training, and emerging requirements of the society, of which environment education is one.

The National Conservation Strategy for this purpose has suggested a revision of curricula along with an addition of environmental component at the Bachelor's and Master's levels and all professional educational institutions. Development of separate departments for environment in the Agricultural and Engineering Universities has also been suggested. The National Education Policy along with other areas of concentration has mentioned an introduction of new disciplines/ emerging sciences in the universities, however, with no particular reference to 'environment' as a discipline. The proposed curricula changes pertain to structural change for conformity with industrial needs rather than a change for deeper understanding of the environment, its interaction with humans and the interdependence of one on the other. Provisions for emergence of environment departments within Agricultural and Engineering Universities as proposed by the National Conservation Strategy have not been made. In fact, at the higher education level, the concepts of environment and sustainable development have hardly been touched.

Chapter NO. 9 "SUPPORTING PROGRAMS" of the National Conservation Strategy of Pakistan has emphasized the significance of education for promoting ESD.

A brief summary of the section on education is as follows:

Pakistan urgently needs to align its education system and curriculum to the dictates of sustainable development. To accomplish this, efforts must be made both to strengthen and reinforce the education curricula at all levels, so as to develop educated believers and practitioners of sustainable development.

The objectives of education on sustainable development are to help individuals and groups within society to:

- Become aware of and sensitive to the total environment and its allied problems.

- Acquire basic knowledge about the environment, its associated problems and humanity's critical presence and role in it.

- Learn skills and expertise for anticipating, avoiding and solving environmental problems.

- Develop the ability to contribute to and evaluate environmental policies, measures and programs.

- Develop a sense of responsibility and urgency leading to a direct participation in appropriate action. 
(Excerpts from the section on Education, NCS of Pakistan)

The mid term review of NCS shows that Pakistan is leg behind in achieving environmental sustainability. Many development constraints remain within Pakistan. These have affected the delivery of NCS programs. These constraints include: unequal economic growth and escalating poverty, gender concerns, and absence of political commitment and will, exclusion of majority of population in decision-making process at grass root level, rapid environmental degradation and failure of institutions to provide frameworks for integration of ESD related themes into their existing courses (Zehra, Samdani, Bouzahar, \& Hanson, 2000).

What does it require to integrate ESD theme in Academic Courses at University level? This is the significant question that needs to be tackled?

No doubt, the role of higher education institutions is important as well as multifaceted. Higher education is synonymous with development of trained personnel. Report(2008) on International Commission on Education for Sustainable Development Practice reveals that "While many universities around the world offer graduate degree programs that have a "development" label, programs typically focus on either social sciences or environmental sciences, and offer few opportunities for systematic, cross disciplinary education or management training. Across these programs, there are no consistent standards for prerequisite training, core curriculum or program length. The acquisition of practical skills requires opportunities for reflective experimentation and "hands-on" experiences, yet too few programs stimulate learning around functional and practical knowledge, and students' opportunities for course-related field work or internships remain rare."

Gayford ( 2001) advocates that Education for Sustainable Development should be through developing pupils' skills in decision making on the basis of sound science, the exploration of values and ethics relating to the applications of science and technology, and developing pupils' knowledge and understanding and understanding of key concepts, such as diversity and interdependence.

The existing situation in Pakistan calls for higher education institutions to make shift from their present roles. Majority of our higher education institutions are engaged in knowledge transmission rather than knowledge generation. Research and development should be the major concern of these institutions. The concepts such as Environmental Education, Education for Sustainability, Peace Education, Human Rights Education, Gender Studies, Service Learning, and HIV AIDS Education have emerged as cross cutting themes in the world. Unfortunately our institutions have not given due importance to these areas. At present, hardly any university of Pakistan is offering degree programs (Masters and Doctorate) in Education for Sustainable Development or Environmental Education \& Environmental Management and Built Environment. There is dearth of faculty members in these areas in the universities of Pakistan.

\section{Suggestion}

The transition towards sustainability can be seen a transforming process of social learning, in which the role of academia is not one of integration of sustainable issues, but one of innovation and systematic change in our institutions. The universities in Pakistan not only 
integrate Education for sustainability concepts into their existing courses but can also motivate civil society for improving the situation. Building a healthy relationship between institutes of higher learning and industries can promote environmental friendly technologies.

As earlier mentioned, the integration of ESD themes requires proper knowledge and skills. Education for Sustainable development can not be taught by using a single approach (i.e. lecturing). As, this approach is prominent in our institutions. The pedagogy of teaching environmental sustainability requires adopting constructivist approach of learning that includes brainstorming, group work, inquiry, field work etc), therefore it is necessary to build the knowledge and skills of universities in teaching concepts relating to Education for Sustainable development. In this connection the link of Higher education institutions with leading teacher education institutions of Pakistan will be a good omen.

Pakistan is facing a problem of food, water and energy shortage. The Engineering and Agriculture Universities of Pakistan can find the solution of these problems by researching on new form of seeds and environmental -friendly new forms of technologies that are renewable such as biomass, solar and wind energy. The universities should introduce new concepts such as "Clean Energy- a Vision of the Future" This will open up new vistas of knowledge not for faculty members but also for students. The SZABIST's Renewable Energy Centre, situated in Thatta is an excellent example for other institutions of Pakistan.

The Universities should start integration of ESD related concepts into their bachelor and mater programs on priority basis. The themes related to biodiversity, ecoregions of Pakistan, natural resources, plants, energy resources, and climate change can be incorporated. In past, it has been observed that majority of our institutions have organized different workshops and refresher courses in environmental education and related concepts but majority of them have focused on the one or two dimensions of environmental educations i.e. awareness or knowledge aspects. There is need to focus on other aspects such as development of skills to solve environmental problems, taking informed and committed action and encouraging participation at all levels to tackle environmental problems. There is need to change our life styles. The life styles that promote sustainable practices in all aspects of life will be a milestone to attain sustainable development.

\section{Conclusion}

There is a long way to go; government cannot alone achieve the targets set in National Conservation Strategy of Pakistan. Achieving environmental sustainability in all walks of life require partnership, exploring, mobilizing and using resources efficiently, and a commitment to save the planet. The improved form of the theory of Education for Sustainable Development (Åhlberg, 2004) highlights the increased importance of culturally sustainable development. It highlights ability, competence, expertise, intelligence, creativity, and wisdom for all aspects of sustainable development. It is the educational core of sustainable development. 


\section{References}

Åhlberg, M. (2004). Education for Sustainable Development: Theoretical underpinnings and practical methods. Concept Maps: Theory, Methodology, Technology. University of Helsinki, Finland Retrieved from http://savonlinnakampus.joensuu.fi/ahlberg/index_cv.htm on April, 22, 2008.

Alvi, U., \& Aziz, A. (2002). Environmental education: Study guide. Karachi: The Aga Khan University-Institute for Educational Development.

Arif, R. (1997). Status of environmental education in sustainable development strategies of Pakistan. Retrieved February 15, 2008, from http://edu.iucnp.org/edu/in.pdf

IUCN. (1999). Briefing note on the integration of poverty-environment linkages in Pakistan's PRSP. DFID. GHK International Ltd. (UK) in Partnership with IUCUN

Pakistan. Retrieved January13, 2004 , from http://www.iucn.org/places/pakistan/poverty/docs/Final\%20Report-3.pdf

Government of Pakistan, Ministry of Education. (2002). Teacher education and training of managers. Retrieved March 15, 2004, from http:// www.pakistan.gov.pk/education_ministry/highlights/NEP-teacher-edu.jsp

Government of Pakistan, Ministry of Environment. (2003). Promotion of environmental education at school and college level project. Islamabad: Pakistan.

Gayford, C. (2001).Education for Sustainable development: an approach to the professional development of teaches. European Journal of Teacher Education, 24, 3, Association for Teacher Education in Europe.

Gupta, A. (2007).A Study of existing perceptions/ Understanding of Education for Sustainable Development of Indian Teachers. Prithvi Innovations, Lucknow.

Report (2008). International Commission on Education for Sustainable Development Practice. The Earth Institute at Columbia University.

UNESCO-UNEP (1994). An environmental education dimension of curriculum for primary School in the ASEAN Region. Environmental Education Series 40. Division for the Renovation of Educational Curricula and Structures. Paris: $\quad$ UNESCO-UNEP.

Zehra, M., Samdani, G., Bouzahar, A., \& Hanson, A. (2000). Pakistan/s National Conservation Strategy: Renewing Comment to Action. (Report of the Mid- term Review). Retrieved February13, 2004, from www.nssd.net/pdf/mtrch1.pdf 